\title{
PENGARUH MODEL PEMBELAJARAN KOOPERATIF TIPE GROUP INVESTIGATION (GI) DENGAN TEKNIK OPEN-ENDED PROBLEM TERHADAP AKTIVITAS DAN HASIL BELAJAR FISIKA SISWA SMAN 3 MATARAM
}

\author{
Rahmatullah, Hairunnisyah Sahidu, Syahrial Ayub \\ Program Studi Pendidikan Fisika \\ FKIP, Universitas Mataram \\ Jalan Majapahit No. 62, Mataram \\ E-mail: rahmatismail6@gmail.com
}

\begin{abstract}
Abstrak - This is a quasi experiment research with nonequivalent control group design. This research aimed to examine the effect of cooperative learning model type GI with open-ended problem technique toward activity and physics learning outcome of students. The population of this research is all students of class XI IPA SMAN 3 Mataram in academic year 2016/2017. The Sampling technique used is purposive sampling to get the students of class XI IPA 6 as experiment group and XI IPA 5 as control group. The experiment group was treated with cooperative learning model type GI with open-ended problem technique while control group was treated with cooperative learning model type GI. The instruments used for learning activities are non-test instruments in the form of observation sheets and to measure the physics learning outcome used test instruments with multiple choice form. The research hypothesis was tested using manova test and t-test pooled variance. The results showed that there was an effect of cooperative learning model type GI with open-ended problem technique towards activity and physics learning outcome of the students.
\end{abstract}

Keywords: cooperative learning model type GI, open-ended problem technique, activity, learning outcome

\section{PENDAHULUAN}

Fisika adalah bagian dari sains (IPA) yang pada hakekatnya berupa kumpulan pengetahuan, cara berpikir, dan penyelidikan. Fisika dapat dipandang sebagai suatu proses dan sekaligus produk sehingga dalam pembelajarannya harus mempertimbangkan strategi atau metode pembelajaran yang efektif dan efisien. Fisika juga memiliki beberapa konsep yang abstrak, artinya konsep tersebut datang dari imajinasi ilmuan yang hanya dapat dijelaskan secara teoritis (Suseno, 2014). Adanya materi yang berisi konsep-konsep abstrak ini menjadi tantangan yang dihadapi guru untuk mengelola pembelajaran fisika yang baik dan menarik bagi siswa.

Pembelajaran fisika menekankan pada pemberian pengalaman langsung untuk mengembangkan kompetensi siswa
(Hermansyah et. al., 2015). Pembelajaran fisika yang dikelola guru sebaiknya berpusat pada siswa karena keberhasilan proses pembelajaran bukan hanya ditentukan oleh aktivitas guru melainkan juga aktivitas siswa itu sendiri. Oleh karena itu guru perlu meningkatkan aktivitas siswa guna mengembangkan kemampuan berpikir yang dimilikinya. Tanpa adanya aktivitas maka belajar tidak mungkin terjadi, sehingga ada atau tidaknya belajar dicerminkan dari ada atau tidaknya aktivitas (Widodo, 2013).

Berdasarkan hasil observasi peneliti di kelas XI IPA 5 dan XI IPA 6 SMAN 3 Mataram ditemukan pembelajaran yang masih berpusat pada guru. Hal tersebut menyebabkan aktivitas siswa menjadi berkurang dan akhirnya berdampak pada rendahnya hasil belajar fisika. 
Kenyataannya siswa hanya mendengarkan dan mencatat semua informasi yang disampaikan oleh guru. Tidak jarang aktivitas siswa di dalam kelas hanya mengerjakan soal-soal latihan yang ada di buku paket maupun buku LKS. Kita ketahui bahwa gejala-gejala yang terjadi di alam sekitar berasal dari konsep fisika. Untuk memahaminya, akan terasa sulit jika siswa hanya mendengarkan dan mencatat penjelasan guru saja. Oleh karena itu, dibutuhkan suatu investigasi melalui kegiatan percobaan agar siswa dapat mengalami suatu proses dalam menemukan konsep itu sendiri.

Salah satu model pembelajaran yang menyedikan kesempatan untuk melakukan investigasi dalam pengembangan suatu konsep adalah model pembelajaran kooperatif tipe GI. Menurut Jannah et. al. (2015) model pembelajaran kooperatif menitik beratkan pada perumusan masalah dari suatu keadaan yang terjadi baik dilakukan sebelum, ketika, atau sesudah pemecahan masalah.

Model pembelajaran kooperatif tipe GI merupakan model pembelajaran yang berhubungan dengan hal-hal semacam penguasaan, analisis dan mensintesis informasi sehubungan dengan menyelesaikan masalahmasalah yang bersifat multi aspek (Slavin, 2005). Model pembelajaran ini menuntut para siswa untuk memiliki kemampuan yang baik dalam menginvestigasi serta keterampilan dalam berkomunikasi dengan kelompok. Jadi selain memberikan ruang untuk mengembangkan pola pikirnya, siswa juga dapat menambah pengetahuan dengan harapan hasil belajarnya akan meningkat. Hasil belajar adalah kemampuan yang dimiliki siswa setelah melakukan pembelajaran (Mutmainnah et. al., 2017).

Adapun fase dalam model pembelajaran kooperatif tipe GI menggunakan 6 fase yaitu fase pemilihan topik, fase perencanaan kooperatif, fase implementasi, fase analisis dan sintesis, fase presentasi hasil serta fase evaluasi. Fase tersebut berada pada kegiatan inti pembelajaran.

Suatu model pembelajaran tentu memiliki kelebihan dan kekurangan. Kelebihan model GI menurut Nurhayati dalam Dewi et. al. (2012) antara lain memberi kebebasan kepada siswa untuk dapat berpikir secara analitis, kritis, kreatif, reflektif dan produktif. Kekurangan dari model GI menurut Kurniasih dalam Fatmawati et. al. (2016) adalah pelaksanaannya membutuhkan waktu yang lama serta setiap kelompok menerima materi yang berbeda-beda sehingga kemungkinan di setiap kelompok hanya akan memahami materinya saja.

Berdasarkan kelebihan dan kekurangan dari model tersebut, maka peneliti menggabungkan model pembelajaran kooperatif tipe GI dengan teknik open-ended problem dengan tujuan untuk saling menutupi kekurangan dari model dan teknik tersebut sehingga pembelajaran yang dilakukan dapat tercapai maksimal. Menurut Uhti (2011), openended merupakan salah satu pendekatan yang memberikan keluasan berpikir siswa secara aktif dan kreatif menyelesaikan suatu permasalahan. Open-ended problem dapat diartikan sebagai masalah terbuka yang digunakan untuk menemukan suatu konsep atau membuktikan suatu konsep.

Masih sedikitnya penelitian yang menggunakan model pembelajaran kooperatif tipe GI yang digabung dengan teknik openended problem membuat peneliti merasa tertarik untuk mengujinya dalam pelajaran fisika. Besar harapan peneliti dengan model pembelajaran kooperatif tipe GI dengan teknik open-ended problem dapat meningkatkan aktivitas dan hasil belajar fisika siswa di SMA. 


\section{METODE PENELITIAN}

Jenis penelitian ini adalah kuasi eksperimen dengan desain nonequivalent control group design. Desain ini digambarkan pada Tabel 1 berikut (Sugiyono, 2013).

Tabel 1. Desain Penelitian

\begin{tabular}{lccc}
\hline Kelas & $\begin{array}{c}\text { Tes } \\
\text { awal }\end{array}$ & Perlakuan & $\begin{array}{c}\text { Tes } \\
\text { akhir }\end{array}$ \\
\hline Eksperimen & $\mathrm{O}_{1}$ & $\mathrm{X}_{1}$ & $\mathrm{O}_{2}$ \\
Kontrol & $\mathrm{O}_{3}$ & $\mathrm{X}_{2}$ & $\mathrm{O}_{4}$ \\
\hline
\end{tabular}

Berdasarkan tabel tersebut kelas eksperimen dan kelas kontrol terlebih dahulu diberikan tes awal secara bersamaan yaitu $\mathrm{O}_{1}$ dan $\mathrm{O}_{3}$. Tujuannya adalah untuk mengetahui kemampuan awal siswa dari sampel yang diambil serta mengetahaui homogenitas dari suatu sampel. Adapun setelah melakukan tes awal, kemudian siswa melaksanakan pembelajaran dengan perlakuan berbeda. Pada penelitian ini kelas eksperimen diberi perlakuan $\left(\mathrm{X}_{1}\right)$ dengan model pembelajaran kooperatif tipe GI dengan teknik open-ended problem. Kelas kontrol diberi perlakuan $\left(\mathrm{X}_{2}\right)$ dengan model pembelajaran kooperatif tipe GI. Untuk mengetahui hasil dari perlakuan yang diberikan maka dilakukan tes akhir secara bersamaan yaitu $\mathrm{O}_{2}$ dan $\mathrm{O}_{4}$.

Populasi yang digunakan yaitu seluruh siswa kelas XI IPA di SMAN 3 Mataram tahun pelajaran 2016/2017. Pengambilan sampel menggunakan teknik purposive sampling sehingga didapatkan kelas XI IPA 5 sebagai kelas kontrol dan kelas XI IPA 6 sebagai kelas eksperimen. Teknik ini dilakukan karena beberapa pertimbangan, yaitu kemampuan awal siswa, guru mata pelajaran yang sama, serta waktu pembelajaran.

Penelitian ini memiliki 3 jenis variabel yaitu variabel bebas seperti model pembelajaran kooperatif tipe GI dengan teknik open-ended problem, variabel terikat seperti aktivitas dan hasil belajar, variabel kontrol seperti materi ajar, guru yang mengajar serta instrument penilaian.

Penelitian ini mengukur aktivitas dan hasil belajar fisika siswa. Untuk mengukur aktivitas belajar menggunakan instrumen non tes dalam bentuk lembar observasi sedangkan hasil belajar siswa menggunakan instrument tes berbentuk pilihan ganda. Sebelum tes pilihan ganda digunakan, terlebih dahulu dilakukan uji validitas sehingga diperoleh 25 soal yang valid dari 30 soal yang diujikan.

Data aktivitas belajar diperoleh dengan lembar observasi yang digunakan oleh observer. Setiap indikator aktivitas pada lembar observer diberi skor 1-4. Skor 1 diberikan jika aktivitas yang diharapkan tidak muncul. Skor 2 diberikan jika aktivitas yang diharapkan jarang muncul. Skor 3 diberikan jika aktivitas yang diharapkan sering muncul. Skor 4 diberikan jika aktivitas yang diharapkan selalu muncul. Total skor yang didapatkan kemudian di konversi ke skala 100 dengan persamaan:

$$
\text { Nilai }=\frac{\text { Skor yang diperoleh }}{\text { skor maksimum }} \times 100
$$

Setelah nilai aktivitas belajar didapatkan, kemudian dibandingkan dalam ketegori sebagai berikut (Sahidu, 2013).

Tabel 2. Kriteria Penilaian Aktivitas Belajar Fisika Siswa

\begin{tabular}{cc}
\hline Konversi Nilai & Kriteria \\
\hline $90-100$ & Sangat aktif \\
$80-89$ & Aktif \\
$65-79$ & Cukup aktif \\
$55-64$ & Kurang aktif \\
$<55$ & Tidak aktif \\
\hline
\end{tabular}

Pengumpulan data untuk hasil belajar dilakukan dengan menggunakan evaluasi. Setiap item soal yang dijawab benar diberi skor 1 sedangkan soal yang salah (tidak dijawab) mendapatkan skor 0. Nilai yang diperoleh siswa dihitung dengan persamaan:

$$
\text { Nilai }=\frac{\text { Skor yang diperoleh }}{\text { skor maksimum }} \times 100
$$


Uji homogenitas dan uji normalitas digunakan setelah mendapatkan data yang diinginkan. Tujuannya adalah untuk mengetahui sebaran data serta memilih persamaan yang akan digunakan untuk menguji hipotesis yang diajukan.

\section{HASIL DAN PEMBAHASAN}

Hasil penelitian berupa deskripsi hasil observasi aktivitas belajar serta hasil tes awal dan tes akhir dengan menggunakan uji normalitas, uji homogenitas dan uji hipotesis.

\section{Deskripsi Data Aktivitas Belajar}

Aktivitas belajar siswa dinilai menggunakan lembar observasi berdasarkan kriteria tertentu. Adapun aktivitas belajar yang dinilai berupa aktivitas visual, aktivitas mendengarkan, aktivitas mental, aktivitas lisan, aktivitas menulis dan aktivitas emosional. Rekapitulasi hasil penilaian aktivitas belajar fisika siswa dapat dilihat pada Tabel 3 berikut.

Tabel 3. Rekapitulasi Aktivitas Belajar Fisika Siswa

\begin{tabular}{lcc}
\hline \multicolumn{1}{c}{ Deskripsi } & $\begin{array}{c}\text { Kelas } \\
\text { Eksperimen }\end{array}$ & $\begin{array}{c}\text { Kelas } \\
\text { Kontrol }\end{array}$ \\
\hline Jumlah Siswa & 42 & 36 \\
Nilai Tertinggi & 89 & 87 \\
Nilai Terendah & 72 & 60 \\
Rata-rata & 78,262 & 75,917 \\
Uji Normalitas & Normal & Normal \\
Uji Homogenitas & \multicolumn{2}{c}{ Homogen } \\
\hline
\end{tabular}

Berdasarkan Tabel 3 terlihat bahwa kelas eksperimen memiliki nilai aktivitas yang berbeda dengan kelas kontrol. Kelas eksperimen memiliki nilai rata-rata aktivitas belajar lebih besar dibandingkan kelas kontrol. Kelas eksperimen memiliki nilai rata-rata 78,262 sedangkan kelas kontrol yang memiliki nilai rata-rata 75,917 .

Secara terperinci didapatkan bahwa kelas eksperimen memiliki kategori sangat aktif, kurang aktif dan tidak aktif sebanyak 0\%, kategori aktif sebanyak 28,5\% dan kategori cukup aktif sebanyak 71,5\%. Lain halnya dengan kelas kontrol yang memiliki kategori sangat aktif dan tidak aktif sebanyak 0\%, kategori aktif sebanyak 19,4\%, kategori cukup aktif sebanyak $77,7 \%$ serta kategori kurang aktif sebanyak 2,7\%. Perbedaan persentase kategori aktif dan kurang aktif mengindikasikan kelas eksperimen memiliki aktivitas yang lebih tinggi dibanding kelas kontrol.

Setelah memperoleh data aktivitas belajar fisika siswa selanjutnya dilakukan uji normalitas. Persamaan uji normalitas menggunakan Chi-Kuadrat. Perhitungan pada taraf signifikasi 5\% menghasilkan $\chi_{\text {hitung }}^{2}$ kelas eksperimen sebesar 5,168 dan $\chi_{\text {hitung }}^{2}$ kelas kontrol sebesar 4,037. Sementara itu dengan derajat kebebasan (dk) sebesar 5 didapatkan nilai $\chi_{\text {tabel }}^{2}$ yaitu 11,070. Hal ini menunjukkan bahwa data aktivitas belajar siswa kedua kelas terdistribusi normal. Oleh karena itu dalam pengujian hipotesis digunakan persamaan parametrik yaitu uji-t.

Selanjutnya dilakukan uji homogenitas dengan tujuan untuk mengetahui persamaan (uji-t) yang akan digunakan dalam melakukan uji hipotesis. Uji homogenitas menggunakan persamaan uji-F. Berdasarkan hasil perhitungan didapatkan nilai $F_{\text {hitung }}$ sebesar 1,490. Pada taraf signifikan $5 \%$ didapatkan juga nilai $\mathrm{F}_{\text {tabel }}$ sebesar 1,708. Karena $F_{\text {hitung }}<F_{\text {tabel }}$ maka dapat dikatakan data aktivitas belajar fisika siswa tersebut homogen. Sehingga persamaan uji-t yang digunakan yaitu polled variance.

\section{Deskripsi Data Hasil Belajar}

Berdasarkan data yang diperoleh, besar nilai rata-rata tes awal hasil belajar fisika siswa kelas eksperimen adalah 40,000 sedangkan nilai rata-rata tes awal kelas kontrol adalah sebesar 39,333. Sementara itu untuk tes akhir hasil belajar fisika siswa kelas eksperimen maupun kelas kontrol didapatkan nilai rata-rata 
berturut-turut sebesar 82,476 dan 75,222. Lebih

jelasnya, data hasil tes awal dan tes akhir dari hasil belajar fisika untuk kelas eksperimen dan kelas kontrol dapat dilihat pada Tabel 4 berikut.

Tabel 4. Hasil Tes Awal dan Tes Akhir Kelas Eksperimen dan Kelas Kontrol

\begin{tabular}{|c|c|c|c|c|}
\hline \multirow[b]{2}{*}{ Deskripsi } & \multicolumn{2}{|c|}{ Tes Awal } & \multicolumn{2}{|c|}{ Tes Akhir } \\
\hline & $\begin{array}{c}\text { Kelas } \\
\text { Eksperimen }\end{array}$ & $\begin{array}{c}\text { Kelas } \\
\text { Kontrol }\end{array}$ & $\begin{array}{c}\text { Kelas } \\
\text { Eksperimen }\end{array}$ & $\begin{array}{c}\text { Kelas } \\
\text { Kontrol }\end{array}$ \\
\hline Jumlah Siswa & 42 & 36 & 42 & 36 \\
\hline Nilai Tertinggi & 64 & 72 & 100 & 88 \\
\hline Nilai Terendah & 24 & 16 & 72 & 68 \\
\hline Rata-rata & 40,000 & 39,333 & 82,476 & 75,222 \\
\hline Uji Normalitas & Normal & Normal & Normal & Normal \\
\hline Uji Homogenitas & \multicolumn{2}{|c|}{ Homogen } & \multicolumn{2}{|c|}{ Homogen } \\
\hline
\end{tabular}

Berdasarkan data tes awal pada Tabel 4 terlihat bahwa kemampuan awal siswa antara kelas eksperimen dan kelas kontrol tidak memiliki perbedaan sehingga dapat dikategorikan sama. Hal ini dikarenakan data tes awal yang didapatkan pada kedua kelas adalah homogen. Dapat dijelaskan juga bahwa terdapat peningkatan hasil belajar fisika siswa pada kelas eksperimen dan kelas kontrol. Hal ini ditandai dengan adanya kenaikan nilai ratarata siswa setelah diberi perlakuan. Kelas eksperimen mengalami peningkatan lebih tinggi dibanding kelas kontrol. Untuk kelas eksperimen mengalami peningkatan sebesar 42,476 sedangkan untuk kelas kontrol mengalami peningkatan sebesar 35,889 . Berikut digambarkan peningkatan hasil belajar siswa dalam bentuk grafik pada Gambar 1 .

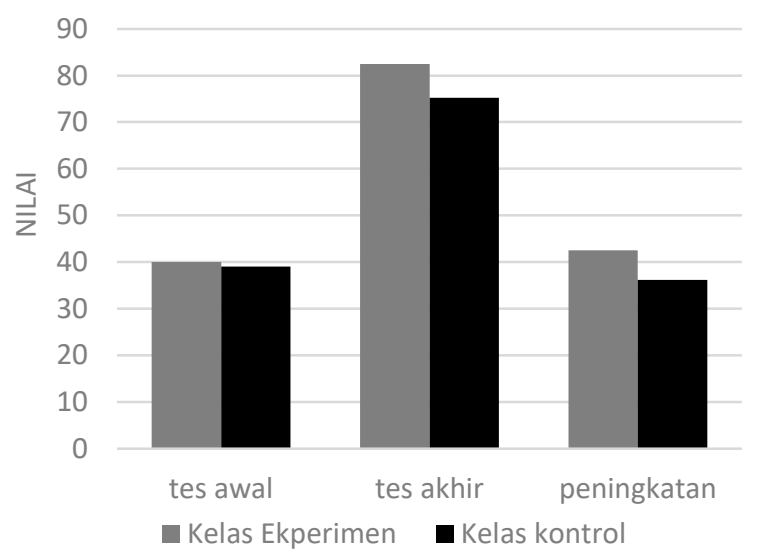

Gambar 1. Perbedaan peningkatan nilai tes hasil belajar fisika siswa
Data hasil belajar yang didapatkan pada tes akhir selanjutnya dilakukan uji normalitas. Perhitungan pada taraf signifikasi 5\% menghasilkan $\chi_{\text {hitung }}^{2}$ kelas eksperimen sebesar 7,625 dan $\chi_{\text {hitung }}^{2}$ kelas kontrol sebesar 4,530. Sementara itu dengan derajat kebebasan (dk) sebesar 5 didapatkan nilai $\chi_{\text {tabel }}^{2}$ yaitu 11,070. Hal ini menunjukkan bahwa data hasil belajar fisika siswa kedua kelas terdistribusi normal. Oleh karena itu dalam pengujian hipotesis digunakan persamaan parametrik yaitu uji-t.

Selanjutnya dilakukan uji homogenitas dengan tujuan untuk mengetahui persamaan (uji-t) yang akan digunakan dalam melakukan uji hipotesis. Uji homogenitas menggunakan persamaan uji-F. Berdasarkan hasil perhitungan didapatkan nilai $F_{\text {hitung }}$ sebesar 1,260. Pada taraf signifikan $5 \%$ didapatkan juga nilai $F_{\text {tabel }}$ sebesar 1,731. Karena $F_{\text {hitung }}<F_{\text {tabel }}$ maka dapat dikatakan data hasil belajar fisika siswa tersebut homogen. Sehingga persamaan uji-t yang digunakan yaitu polled variance.

\section{Uji Hipotesis}

Pada penelitian ini terlebih dahulu dilakukkan pengujian hipotesis terhadap dua variabel terikat sekaligus. Uji Hipotesis yang digunakan untuk mengukur dua variabel terikat secara bersamaan yaitu Uji Manova. Berdasarkan Hasil uji Manova didapatkan nilai $F_{\text {hitung }}$ sebesar 13,201. Pada taraf signifikan 5\% 
didapatkan nilai $F_{\text {tabel }}$ sebesar 1,703. Oleh karena nilai $F_{\text {hitung }}>F_{\text {tabel }}$, sesuai prasyarat uji manova maka $\mathrm{H}_{\mathrm{o} 1}$ ditolak artinya bahwa terdapat pengaruh model pembelajaran kooperatif tipe GI dengan teknik open-ended problem terhadap aktivitas dan hasil belajar fisika siswa kelas XI IPA SMAN 3 Mataram tahun pelajaran 2016/2017. Berdasarkan hasil penelitian yang telah dilakukan, terdapat kesamaan hasil dengan penelitian sebelumnya. Artini et. al. (2015) menyimpulkan bahwa penggunaan model pembelajaran GI dapat meningkatkan aktivitas guru dan siswa di kelas serta menujukkan ketercapaian hasil belajar kognitif, afektif dan psikomotor. Selain itu juga Dewi et. al. (2012) menyatakan model group investigation dapat diterapkan untuk meningkatkan hasil belajar dan aktivitas siswa.

Uji hipotesis lanjut dilakukan untuk mengetahui variabel terikat mana yang lebih dipengaruhi oleh variabel bebas dengan menguji secara terpisah tiap variabel terikatnya. Uji hipotesis kedua yaitu pengaruh terhadap aktivitas belajar fisika siswa. Berdasarkan hasil uji homogenitas dan normalitas data tes akhir, diperoleh data kedua kelas homogen dan terdistribusi normal. Sehingga uji hipotesis yang digunakan yaitu uji statistik parametrik dengan persamaan uji-t polled varians. Berdasarkan hasil perhitungan didapatkan bahwa $t_{\text {hitung }}>t_{\text {tabel }}$ yaitu 2,303 $>1,992$ pada taraf signifikasi sebesar $5 \%$ sehingga $\mathrm{H}_{02}$ ditolak. Artinya bahwa terdapat pengaruh model pembelajaran kooperatif tipe GI dengan teknik open-ended problem terhadap aktivitas belajar fisika siswa kelas XI IPA SMAN 3 Mataram tahun pelajaran 2016/2017.

Hasil penelitian yang sudah dilakukan memperlihatkan bahwa model pembelajaran yang diterapkan pada kelas eksperimen dapat meningkatkan aktivitas belajar siswa. Temuan ini memperkuat beberapa penelitian yang telah dilakukan sebelumnya, diantaranya adalah
Daud et. al. (2011) yang menyatakan bahwa penerapan model pembelajaran kooperatif tipe GI menunjukkan pengaruh yang signifikan terhadap aktivitas belajar siswa.

Teknik open-ended problem memberikan pengaruh dimana siswa merasa tertarik untuk melakukan investigasi. Sehingga tiap-tiap siswa mencoba menemukan sesuatu dengan sendirinya karena sudah dipengaruhi oleh penugasan diawal dalam bentuk tugas openended problem. Sesuai dengan pendapat Murni (2013) yang mengatakan bahwa pembelajaran dengan menggunakan pendekatan open-ended dapat membangun aktivitas interaktif antara siswa dan pelajaran dengan tujuan menarik siswa untuk menjawab permasalahan menggunakan strategi atau cara apapun.

Soal terbuka yang diberikan akan membuat siswa lebih terangsang untuk menemukan banyak solusi dari masalah yang diberikan (Afandi, 2013). Masalah yang harus dipecahkan secara individu memberikan stimulus kepada siswa untuk mencari tahu. Yusuf et. al. (2009) mengatakan bahwa soal open-ended dapat memunculkan ide kreatif siswa dalam menyelesaikan soal. Sehingga dalam pembelajarannya muncul beragam aktivitas akibat dari minat mereka dalam menemukan solusi. Terlebih lagi dibantu dengan investigasi secara berkelompok. Investigasi memberikan kesempatan siswa untuk mempelajari ilmu dengan sendirinya dan mengolahnya dengan baik.

Proses belajar mengajar fisika materi pokok fluida statis menggunakan open-ended problem dapat merangsang siswa untuk lebih aktif dalam mengikuti kegiatan pembelajarannya. Suasana kelas menjadi lebih hidup dan siswa bersemangat mengikuti proses pembelajaran. Siswa juga terlihat lebih aktif dalam hal mengajukan pertanyaan serta memberikan kritik dan saran. Hal ini menunjukkan ketertarikannya dalam mengikuti 
pembelajaran dengan model dan teknik yang digunakan.

Selanjutnya dilakukan uji hipotesis yang ketiga yaitu terhadap hasil belajar fisika siswa. Data yang didapatkan pada tes akhir yaitu homogen dan terdistribusi normal. Berdasarkan hasil perhitungan terlihat bahwa $t_{\text {hitung }}>$ $t_{\text {tabel }}$ yaitu 5,426 $>1,992$ pada taraf signifikasi 5\% sehingga $\mathrm{H}_{03}$ ditolak. Artinya, terdapat pengaruh model pembelajaran kooperatif tipe GI dengan teknik open-ended problem terhadap hasil belajar fisika siswa kelas XI IPA SMAN 3 Mataram tahun pelajaran 2016/2017. Hasil penelitian yang didapatkan mendukung beberapa penelitian sebelumnya diantaranya penelitian yang dilakukan oleh Putra et. al. (2015) menyatakan bahwa model pembelajaran kooperatif tipe GI (Group Investigation) berbantuan multimedia interaktif berpengaruh terhadap hasil belajar IPA. Serta dalam penelitian lain disebutkan bahwa soal openended yang dikembangkan memiliki efek potensial yang positif terhadap hasil tes siswa (Mardayanti et. al., 2016).

Untuk mengetahui lebih terperinci terkait peningkatan hasil belajar fisika siswa pada kelas eksperimen maupun kelas kontrol maka dilakukan uji N-gain. Berdasarkan perolehan rata-rata nilai $\mathrm{N}$-gain diketahui bahwa peningkatan hasil belajar kelas eksperimen lebih tinggi dibandingkan kelas kontrol. Nilai rata-rata $\mathrm{N}$-gain kelas eksperimen sebesar $71 \%$ sedangkan kelas kontrol sebesar 59\%.

Sementara itu berdasarkan uji N-gain per sub materi didapatkan kesimpulan yang sama yang mana peningkatan hasil belajar kelas eksperimen lebih tinggi dibanding kelas kontrol. Penelitian Pariasa et. al. (2015) menyatakan bahwa masalah terbuka (openended) memiliki pengaruh positif terhadap hasil belajar siswa dibandingkan dengan pembelajaran konvensional. Lebih jelasnya dapat dilihat pada Gambar 2.

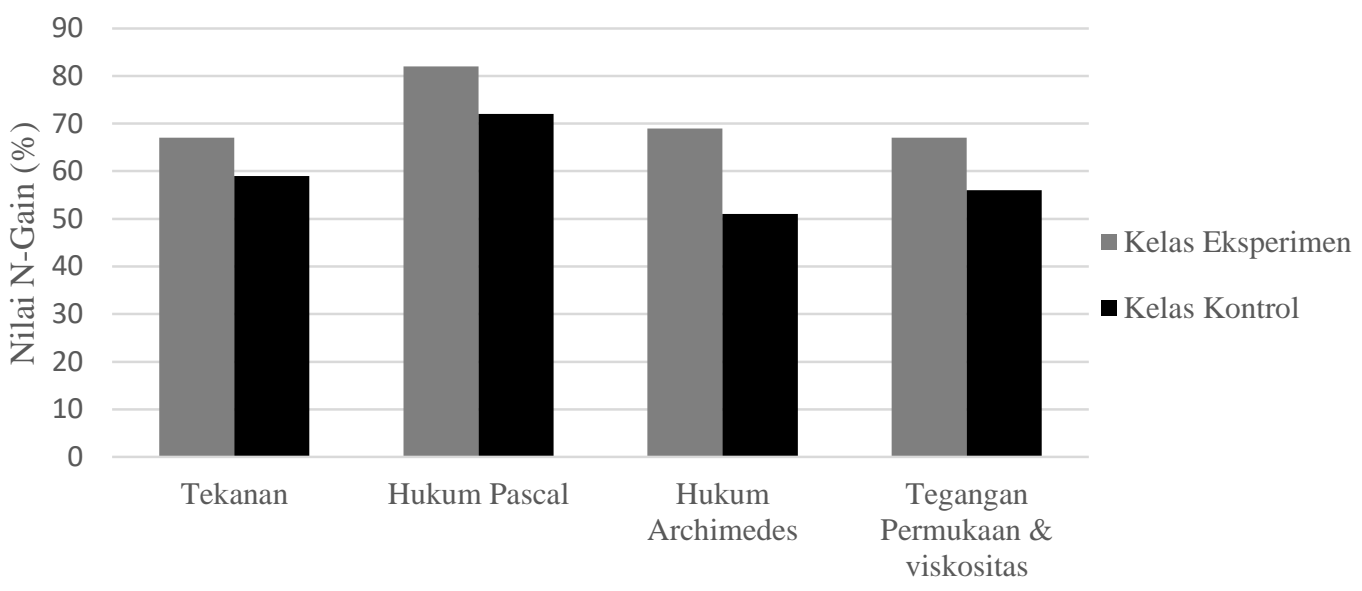

Gambar 2. Perbandingan Nilai N-gain Per Sub Materi

Materi fluida terbagi kedalam empat sub materi yaitu tekanan, hukum Pascal, hukum Archimedes serta tegangan permukaan dan viskositas. Setiap sub materi dianalisis ketercapaiannya berdasarkan perolehan skor tes awal dan tes akhir.

Hasil analisis menjelaskan bahwa persentase $\mathrm{N}$-gain tertinggi kelas eksperimen yaitu pada sub materi hukum Pascal sebesar $82 \%$ dan terendah sebesar $67 \%$ pada sub materi tekanan dan tegangan permukaan. Sedangkan pada kelas kontrol $\mathrm{N}$-gain tertinggi pada sub materi hukum Pascal sebesar $72 \%$ dan terendah hukum Archimedes sebesar 51\%. Sub materi hukum Pascal mengalami peningkatan paling tinggi dikedua kelas. Hal ini disebabkan karena soal hitungan sub materi hukum Pascal lebih 
sedikit dibandingkan sub materi lain. Artinya bahwa siswa lebih mudah memaknai materi pembelajaran dalam bentuk konsep dibanding hitungan.

Selain melihat pengaruh terhadap hasil belajar ranah kognitif, dilakukan juga penilaian terhadap ranah afektif dan psikomotor. Hal ini dilakukan sebagai pendukung aktivitas dan hasil belajar fisika siswa pada ranah kognitif. Pada ranah afektif nilai rata-rata siswa kelas eksperimen lebih besar dari pada kelas kontrol. Nilai rata-rata kelas eksperimen yaitu sebesar 84,226 dengan kriteria baik dan kelas kontrol yaitu sebesar 80,382 dengan kriteria cukup.

Pada ranah psikomotor nilai rata-rata siswa kelas eksperimen juga berbeda dengan kelas kontrol. Berdasarkan data yang didapatkan terlihat bahwa nilai rata-rata hasil belajar ranah psikomotor kelas eksperimen lebih besar dari kelas kontrol. Nilai rata-rata yang diperoleh kelas eksperimen sebesar 77,827 dengan kriteria terampil sedangkan kelas kontrol sebesar 74,479 dengan kriteria cukup terampil.

Suwito (2015) menyatakan pendekatan open-ended efektif ditinjau dari sikap belajar siswa. Akibatnya antusias siswa untuk mengikuti pembelajaran dengan teknik ini meningkat. Hal ini juga berdampak pada aktivitas serta hasil belajarnya.

Kegiatan pembelajaran dalam bentuk investigasi kelompok memungkinkan siswa mengolah pengetahuan tingkat tinggi. Dalam proses pembelajarannya siswa terlebih dahulu diberikan tugas untuk diselesaikan secara individu sehingga tiap siswa mendapatkan pemahaman awal. Untuk lebih memaknai dan memperkuat pemahaman yang didapatkan, selanjutnya siswa diminta menginvestigasi lagi secara berkelompok dengan model pembelajaran kooperatif tipe GI.
Hadirnya open-ended problem ini dapat menutupi kekurangan pembelajaran kooperatif tipe GI yaitu hanya siswa yang memiliki kemampuan lebih yang bekerja dalam satu kelompok. Selain itu juga karena tiap kelompok memiliki sub materi pembahasan yang berbeda maka tidak jarang satu kelompok hanya menguasai atau memahami sub materi yang didapatkan. Oleh karena itu diberikanlah tugas open-ended problem pada tiap siswa dengan berusaha memecahkan persoalan untuk mendapatkan pemahaman materi secara individu. Sehingga pemahaman materi dapat merata disetiap siswa. Dampaknya adalah pengaruh positif terhadap hasil belajar fisika siswa.

\section{PENUTUP}

Berdasarkan hasil dan pembahasan yang telah dipaparkan dapat disimpulkan bahwa Model pembelajaran kooperatif tipe GI dengan teknik open-ended problem berpengaruh terhadap aktivitas dan hasil belajar fisika siswa kelas XI IPA SMAN 3 Mataram Tahun Pelajaran 2016/2017. Model pembelajaran kooperatif tipe GI dengan teknik open-ended problem berpengaruh terhadap aktivitas belajar fisika siswa kelas XI IPA SMAN 3 Mataram Tahun Pelajaran 2016/2017. Model pembelajaran kooperatif tipe GI dengan teknik open-ended problem berpengaruh terhadap hasil belajar fisika siswa kelas XI IPA SMAN 3 Mataram Tahun Pelajaran 2016/2017. Hasil belajar lebih dipengaruhi oleh model pembelajaran kooperatif tipe GI dengan teknik open-ended problem dibandingkan aktivitas belajar. Adapun saran yang dapat diberikan yaitu model pembelajaran kooperatif tipe GI dengan teknik open-ended problem dapat diterapkan oleh guru dalam proses pembelajaran, sebagai salah satu alternatif model pembelajaran yang efektif terhadap hasil belajar siswa serta proses pembelajaran harus 
lebih di optimalkan agar mendapatkan hasil yang lebih baik lagi.

\section{REFERENSI}

Afandi, A. 2013. Pendekatan Open-Ended dan Inkuiri Terbimbing ditinjau dari Kemampuan Pemecahan Masalah dan Representasi Multipel Matematis. Jurnal Pendidikan Matematika. 8 (1), 1-11.

Artini, Pasaribu, M, \& Husain, SM. 2015. Penerapan Model Pembelajaran Kooperatif Tipe Group Investigation Untuk Meningkatkan Aktivitas Dan Hasil Belajar IPA Pada Siswa Kelas VI SD Inpres 1 Tondo. E-Journal Mitra Sains. 3 (1), 45-52.

Daud, F \& Warti, D.W. 2011. Pengaruh Penerapan Model Pembelajaran Kooperatif Tipe Grup Investigasi Terhadap Aktivitas dan Hasil Belajar Siswa Kelas X SMA Negeri 1 Bajeng Pada Konsep Ekosistem. Jurnal Bionature. 12 (1), 45-52.

Dewi, R.P, Iswari, S.R \& Susanti, R. 2012. Penerapan Model Group Investigation Terhadap Hasil Belajar Materi Bahan Kimia di SMP. Unnes Science Education Journal. 1 (2), 69-76.

Fatmawati, D \& Maryatun. 2016. Pengaruh Penggunaan Model Cooperative Learning Tipe Group Investigation (GI) Terhadap Hasil Belajar IPS Terpadu Kelas VIII Semester Genap SMPYPI 1 Bandar Mataram Lampung Tengah T.P 2015/2016. Jurnal Pendidikan Ekonomi. 4 (1), 9-20.

Hermansyah, Gunawan \& Herayanti, L. 2015. Pengaruh Penggunaan Laboratorium Virtual Terhadap Penguasaan Konsep dan Kemampuan Berpikir Kreatif Siswa Pada Materi Getaran dan Gelombang. Jurnal Pendidikan Fisika dan Teknologi. 1(2), 97-102.

Jannah, S.M., Doyan, A. \& Harjono, A. 2015. Pengaruh Model Pembelajaran Kooperatif dengan Pendekatan Problem
Posing Ditinjau Dari Pengetahuan Awal Terhadap Kemampuan Pemecahan Masalah Fisika Siswa SMK. Jurnal Pendidikan Fisika dan Teknologi. 1 (4), 256-263.

Mardayanti, E., Zulkardi \& Santoso, B. 2016. Pengembangan Soal Open-Ended Menggunakan Konteks Sumatera Selatan Materi Sistem persamaan Linear Dua Variabel Kelas X SMA. Jurnal Pendidikan Matematika. 10 (1), 1-14.

Murni. 2013. Open-Ended Approach in Learning to Improve Students Thinking Skills in Banda Aceh. International Journal of Independent Research and Studies. 2 (2), 95-101.

Mutmainnah, Rokhmat, J. \& 'Ardhuha, J. 2017. Pengaruh Penerapan Metode Pembelajaran Fisika Berbasis Eksperimen Virtual Terhadap Motivasi dan Hasil Belajar Fisika Siswa Kelas X MAN 2 Mataram Tahun Ajaran 2014/2015. Jurnal Pendidikan Fisika dan Teknologi. 1 (3), 41-47.

Pariasa, I.K., Arini, N.W \& Japa, I.G.N. 2015. Pengaruh Pendekatan Masalah Terbuka (Open-Ended) Terhadap Hasil Belajar Matematika Siswa Kelas V SD Gugus VII Kec. Tejakula, Tahun Pelajaran 2013/2014. E-Journal PGSD Universitas Pendidikan Ganesha. 3(1), 1-11.

Putra, P.A.D., Sudarma, I.K \& Tegeh, I.M. 2015. Pengaruh Model Pembelajaran Kooperatif TIPE GI (Group Investigation) Berbantuan Multimedia Interaktif TerhadapHasil Belajar IPA. EJournal Edutech Universitas Pendidikan Ganesha. 3 (1), 1-11.

Sahidu, H. 2013. Penilaian Hasil Belajar. Mataram: Arga Puji Press.

Slavin, R.E. 2005. Cooperative learning Teori, Riset dan Praktik. Bandung: Nusa Media.

Sugiyono. 2013. Statistika untuk Pendidikan. Bandung : Alfabeta. 
Suseno N. 2014. Pemetaan Analogi Pada Konsep Abstrak Fisika. Jurnal Pendidikan Fisika. 2 (2), 1-10.

Suwito, Y.R.E. 2015. Kefektifan Pendekatan Open-Ended dan CTL Ditinjau Dari Presentasi dan Sikap Belajar Matematika. Jurnal Derivat. 2(1) 45-57.

Uhti. 2011. Pembelajaran Kooperatif dengan Pendekatan Open-ended Untuk Meningkatkan Kemampuan Pemecahan Masalah Matematis Siswa Sekolah Menengah. Prosiding Seminar Nasional Matematika dan Pendidikan Matematika Yogyakarta, 3 Desember 2011.

Widodo, L.W. 2013. Peningkatan Aktivitas Belajar Dan Hasil Belajar Siswa Dengan Metode Problem Based Learning Pada Siswa Kelas VII A MTs Negeri Donomulyo Kulon Progo Tahun Pelajaran 2012/2013. Jurnal Fisika Indonesia. 8 (49), 32-35.

Yusuf, M., Zulkardi \& Saleh, T. 2009. Pengembangan Soal-soal Open-Ended Pada Pokok Bahasan Segitiga Dan Segiempat Di SMP. Jurnal Pendidikan Matematika. 3 (2), 48-56. 